\title{
ERRATUM
}

\section{Quality of life, health status and clinical outcomes in Type 2 diabetes patients}

\author{
Murali Sundaram · Jan Kavookjian · \\ Julie Hicks Patrick · Lesley-Ann Miller · \\ S. Suresh Madhavan · Virginia (Ginger) Scott
}

Published online: 3 March 2007

(C) Springer Science+Business Media B.V. 2007

Erratum to: Qual Life Res 16: 165-177

DOI 10.1007/s11136-006-9105-0

The fifth author's name was incorrectly coded for abstracting and indexing purposes in the original publication.

The online version of the original article can be found at http:// dx.doi.org/10.1007/s11136-006-9105-0

M. Sundaram $(\bowtie) \cdot$ J. Kavookjian · L.-A. Miller .

S. S. Madhavan · V. (Ginger) Scott

Department of Pharmaceutical Systems and Policy,

West Virginia University School of Pharmacy, 1122-B, R.C.

Byrd Health Sciences Center, P.O. Box 9510, Morgantown,

WV 26506, USA

e-mail: muralisundaram@hsc.wvu.edu

J. H. Patrick

Department of Psychology, West Virginia University,

Morgantown, USA 